A C T A C H E M I C A S C A N D I N A V I C A 27 (1973) $605-612$

\title{
The Inhibition of a p-Nitrophenylphosphatase of Streptococcus mutans by Fluoride Ions
}

\author{
MATTI L. E. KNUUTTILA and KAUKO K. M ÄKINEN \\ Institute of Dentistry, University of Turku, SF-20520 Turku 52, Finland
}

\begin{abstract}
The effect of fluoride ions on the rate of the hydrolysis of $p$-nitrophenylphosphate, catalyzed by a purified $p$-nitrophenylphosphatase of Streptococcus mutans, was studied in the presence and absence of $\mathrm{Mg}^{2+}$ ions. The affinity of $p \cdot$ nitrophenyl phosphate for the enzyme was dependent on the concentration of $\mathrm{Mg}^{2+}$ ions. The kinetic data supported the formation of a $\mathrm{Mg}^{2+}-p$-nitrophenyl phosphate complex in certain conditions. Fluoride ions had most likely reacted with the substrate, when tested at $0.67-1.67 \mathrm{mM} \mathrm{NaF}$. The fluoride ions inhibited the growth of the cells but they had no repressive or inducive effect on the synthesis of the $p$-nitrophenylphosphatase.
\end{abstract}

$\mathrm{O}_{\mathrm{s}}^{\mathrm{n}}$ nly few authors have reported detailed studies on the mode of action of fluoride ions on metal-requiring enzyme reactions. The inhibition of enolase by fluoride ions is one of the best known. ${ }^{1-5}$ Phosphatases, which are often activated by $\mathrm{Mg}^{2+}$ ions, have been studied by several authors ${ }^{6-12}$ as to mode of fluoride inhibition. Hewitt and Nicholas ${ }^{13}$ have listed a number of reasons to explain why anions may exert an inhibitory influence on enzymes.

This paper will provide information about the inhibition by fluoride ions of the hydrolysis of $p$-nitrophenyl phosphate, specifically catalyzed by a purified phosphatase of Streptococcus mutans. The effect of fluoride ions on the synthesis of $p$-nitrophenylphosphatase was also studied. The purification and characterization of this enzyme has been described earlier. ${ }^{14}$

\section{MATERIALS AND METHODS}

1. Effect of fluoride ions on the enzyme reaction. The enzyme hydrolyzing specifically $p$-nitrophenyl phosphate was purified from the cells of Streptococcus mutans (strain Ingbritt) using DEAE cellulose chromatography and isoelectric focusing as the main steps..$^{4}$ The effect of different fluoride ion concentrations on the rate of the hydrolysis of $p$-nitrophenyl phosphate was studied at four substrate concentrations, varying also the amount of $\mathrm{Mg}^{2+}$ ions, which were found to activate the enzyme. The following fluorides were used: $\mathrm{NaF}$ and $\mathrm{LiF}$, obtained from Merck A G (Darmstadt, Germany), and $\mathrm{KF}$, from Baker Chemical Co (Phillipsburg, N.J., USA). The respective chlorides were used as controls. 
The determination of the enzyme activity was based on the method of Bessey et $a l .,^{15}$ which was performed in $0.025 \mathrm{M}$ borate buffer, $\mathrm{pH} 8.0$, as presented earlier. . $^{14}$ If not otherwise stated, the reagents and their sources were the same as mentioned earlier. ${ }^{14}$

2. Effect of fluoride ions on the synthesis of the enzyme. The maintaining of the cells, the preparation of the inoculum medium and the cultivation procedures were the same as earlier. ${ }^{14}$ The growth medium, which was used in the cultivations of the cells for preparing the purified enzyme, was also used in studying the effect of $\mathrm{NaF}$ and $\mathrm{KF}$ on the synthesis of the $p$-nitrophenylphosphatase. This medium was composed as follows: Trypticase TM $(1.7 \mathrm{~g} / 100 \mathrm{ml})$, Phytone ${ }^{\mathrm{TM}}(0.3 \mathrm{~g} / 100 \mathrm{ml})$, glucose $(0.25 \mathrm{~g} / 100 \mathrm{ml}), \mathrm{K}_{2} \mathrm{HPO}_{4}(0.25 \mathrm{~g} / 100$ $\mathrm{ml})$ and $\mathrm{NaCl}(0.5 \mathrm{~g} / 100 \mathrm{ml})$. Fluorides were added before autoclaving to the final concentrations of $0.5,2.1,4.2,8.4$, and $16.8 \mathrm{mM}$.

The rate of the hydrolysis of $p$-nitrophenyl phosphate was determined during the growth of the bacteria in crude preparations resulting from ultrasonic treatments. These crude enzyme preparations were obtained from the cells of $5 \mathrm{ml}$ aliquots of the growth media. The cells were harvested by centrifugation and the pellets, suspended in $0.5 \mathrm{ml}$ of cold $\left(+4^{\circ} \mathrm{C}\right) 0.05 \mathrm{M}$ borate buffer, $\mathrm{pH} 8.0$, were in principle sonicated as earlier. ${ }^{14}$ After sonication the mixtures were centrifuged $\left(10 \mathrm{~min}\right.$ at $12000 \mathrm{~g}$, at $+4^{\circ} \mathrm{C}$, using a Sorwall Superspeed RC-2B centrifuge with rotor SS-34), and the supernatant fluids were used for the determination of the enzyme activity as mentioned above. In two cases where fluoride concentrations were 2.1 and $16.8 \mathrm{mM}$ the crude enzyme preparations were dialyzed against water before the measuring of the rate of the hydrolysis. Thus a possible effect of fluoride ions in the crude enzyme preparations themselves on the enzyme reaction could be ruled out.

\section{RESULTS}

\section{Effect of fluoride ions on the reaction velocity}

Before the effect of fluoride was studied, it was necessary to obtain information about the role of $\mathrm{Mg}^{2+}$ ions in the reaction mechanism. The plots described below were constructed:

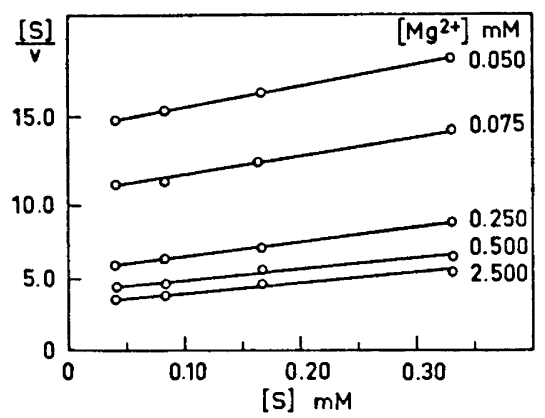

Fig. 1. Hanes' plots of the substrate con. centration divided by the velocity $([\mathrm{S}]) / v$ in $10^{3} \times \mathrm{min}$ ) versus the substrate concentration ([S]; in $\mathrm{mM}$ ) of the hydrolysis of $p$-nitrophenyl phosphate, catalyzed by the $p$-nitrophenylphosphatase from Streptococcus mutans. The values of $K_{\mathrm{s}}$ obtained are: $0.43 \mathrm{mM}$ for $2.50 \mathrm{mM} \mathrm{MgCl}{ }_{2}, 0.53 \mathrm{mM}$ for $0.50 \mathrm{mM} \mathrm{MgCl}{ }_{2}, 0.55 \mathrm{mM}$ for $0.25 \mathrm{mM}$ $\mathrm{MgCl}_{2}, 0.85 \mathrm{mM}$ for $0.075 \mathrm{mM} \mathrm{MgCl}_{2}$, and $1.06 \mathrm{mM}$ for $0.050 \mathrm{mM} \mathrm{MgCl}_{2}$.

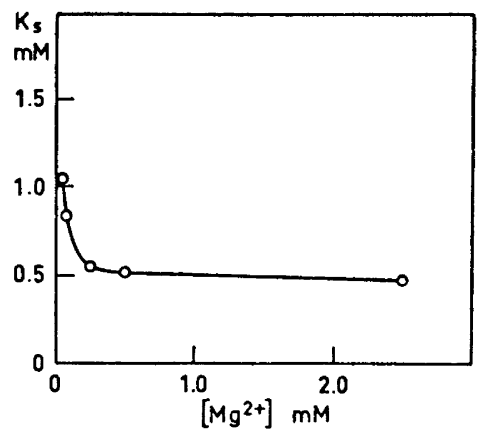

Fig. 2. Dependence of the value of the substrate constants, $K_{\mathrm{s}}$, obtained from Fig. 1, on the concentration of $\mathrm{Mg}^{2+}$ ions in the hydrolysis of $p$-nitrophenyl phosphate, catalyzed by the purified $p$-nitrophenylphosphatase.

Acta Chem. Scand. 27 (1973) No. 2 
(1) A plot of [S]/v versus [S] at different $\mathrm{Mg}^{2+}$ ion concentrations is shown in Fig. 1. The results indicate that $\mathrm{Mg}^{2}{ }^{+}$ions slightly affect the substrate constant, $K_{\mathrm{s}}$. This is also shown in Fig. 2, where the same data were plotted using the values of $K_{\mathrm{s}}$ obtained from Fig. 1 . These figures show that at low concentrations of $\mathrm{Mg}^{2+}$ ions the affinity between the enzyme and substrate is less than that obtained at high $\mathrm{Mg}^{2+}$ concentrations.

(2) A plot of $1 / v$ versus $1 /\left[\mathrm{Mg}^{2+}\right]$ at varying $p$-nitrophenyl phosphate concentrations is shown in Fig. 3. Because there was no detectable change in the value of $K_{\mathrm{s}}$, it was concluded that there is no competition between $p$-nitrophenyl phosphate and $\mathrm{Mg}^{2+}$ ions for the same site of the enzyme. $\mathrm{Mg}^{2+}$ ions were considered to have most likely a separate binding site at the enzyme surface. The concentration of $p$-nitrophenyl phosphate did not affect the affinity of $\mathrm{Mg}^{2+}$ ions for its binding site.

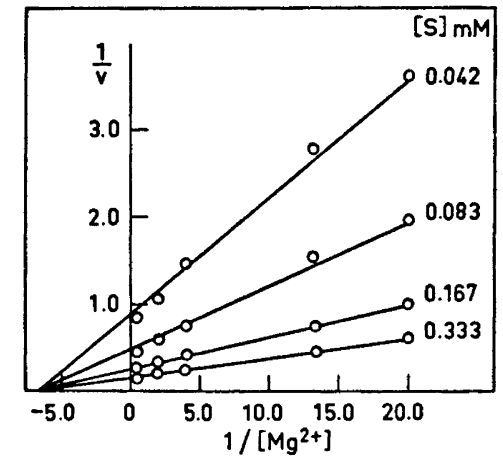

Fig. 3. The plot of the inverse value of the initial velocity $\left(1 / v\right.$; in $\left.\mathbf{M}^{-1} \times \min \times 10^{8}\right)$ versus the inverse value of $\mathrm{MgCl}_{2}$ concentration $\left(1 /\left[\mathrm{Mg}^{2+}\right]\right.$; in $\mathrm{mM}^{-1}$ in the hydrolysis of $p$-nitrophenyl phosphate catalyzed by the purified $p$-nitrophenylphosphatase. Tested at the following $p$-nitrophenyl phosphate concentrations: $0.333 \mathrm{mM}, 0.167$ $\mathrm{mM}, 0.083 \mathrm{mM}$ and $0.042 \mathrm{mM}$.

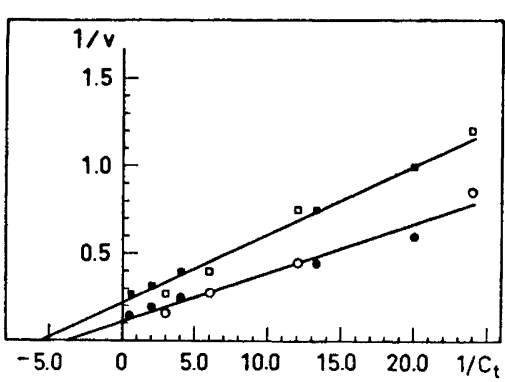

Fig. 4. Equivalence of apparent affinities of $p$-nitrophenylphosphatase for activating $\mathrm{Mg}^{2+}$ ions and substrate. Reciprocal plots for the hydrolysis of $p$-nitrophenyl phosphate catalyzed by the phosphatase $\left(1 / v\right.$ in $\left.\mathrm{M}^{-1} \times \min \times 10^{8}\right) . C_{\mathrm{t}}$ denotes the total molar concentrations of $p$-nitrophenyl phosphate: $0.333 \mathrm{mM}(\mathrm{O})$ (with $2.50 \mathrm{mM}$ $\mathrm{Mg}^{2+}$ ), $0.167 \mathrm{mM}(\square)$ (with $0.25 \mathrm{mM} \mathrm{Mg}^{2+}$ ); and of $\mathrm{Mg}^{2+}$ ions: $2.50 \mathrm{mM}$ (๑) (with 0.333 $\mathrm{mM} p$-nitrophenyl phosphate), $0.25 \mathrm{mM}$ (匹) (with $0.167 \mathrm{mM} p$-nitrophenyl phosphate).

The apparent affinities of the enzyme for $\mathrm{Mg}^{2+}$ ions in the presence of $0.167 \mathrm{mM}$ and $0.333 \mathrm{mM} p$-nitrophenyl phosphate were approximately the same as those for $p$-nitrophenyl phosphate in the presence of $0.25 \mathrm{mM}$ and $2.50 \mathrm{mM}$ $\mathrm{Mg}^{2+}$ ions, respectively (Fig. 4). Consequently, only those concentrations of activator and substrate mentioned above yielded almost the same value for both $K_{\mathrm{A}}$ (the dissociation constant of the Mg-enzyme complex) and $K_{\mathrm{s}}$. The values of $K_{\mathrm{A}}$ and $K_{\mathrm{s}}$ in the conditions indicated above were approximately $0.17 \mathrm{mM}$ and $0.25 \mathrm{mM}$, respectively.

Acta Chem. Scand. 27 (1973) No. 2 


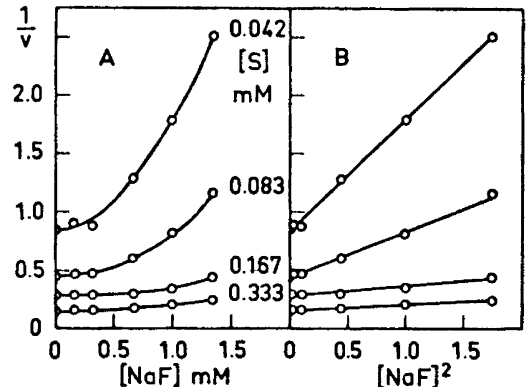

Fig. 5. The Dixon plots of the inverse value of the initial velocity $\left(1 / v_{i}\right.$; in $\left.\mathrm{M}^{-1} \times \min \times 10^{8}\right)$ versus the concentration of $\mathrm{NaF}$ (in $\mathrm{mM}$ ), (A), and the plot of the inverse value of the initial velocity versus the second power of the concentration of NaF, (B). Tested at the following $p$-nitrophenyl phosphate concentrations: $0.333 \mathrm{mM} 0.167 \mathrm{mM}, 0.083 \mathrm{mM}$ and $0.042 \mathrm{mM}$. The used $\mathrm{Mg}^{2}+$ ion concentration was $2.50 \mathrm{mM}$.

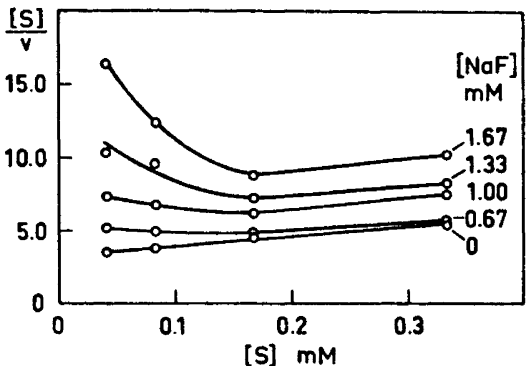

Fig. 6. Hanes' plot of the substrate concentration divided by the velocity ([S] $/ v$ in $10^{3} \times \mathrm{min}$ ) versus the substrate concentration ([S]; in $\mathrm{mM}$ ) of the enzymic hydrolysis of $p$-nitrophenyl phosphate, inhibited by the following $\mathrm{NaF}$ concentrations: $0 \mathrm{mM}, 0.67 \mathrm{mM}, 1.0 \mathrm{mM}, 1.33 \mathrm{mM}$ and $1.67 \mathrm{mM}$. The used $\mathrm{Mg}^{2+}$ ion concentration was $2.50 \mathrm{mM}$.

The effect of fluoride ions on the reaction velocity in the presence of varying $p$-nitrophenyl phosphate concentrations is presented in Figs. 5, 6, 7, and 8 . The figures present the effect of sodium fluoride, but identical results were

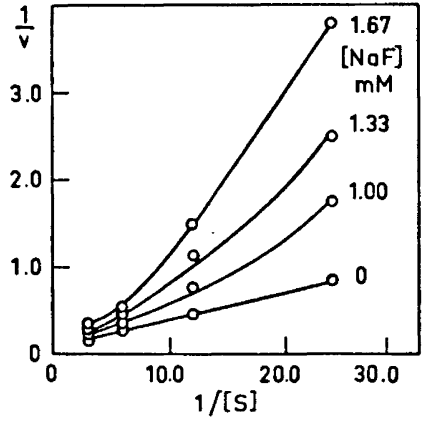

Fig. 7. The data of Fig. 6 plotted according to Lineweaver and Burk (the plot of the inverse value of the initial velocity $(1 / v$; in $\mathrm{M}^{-1} \times \min \times 10^{8}$ ) versus the inverse value of the substrate concentration $(1 /[\mathrm{S}]$; in $\left.\mathrm{mM}^{-1}\right)$.

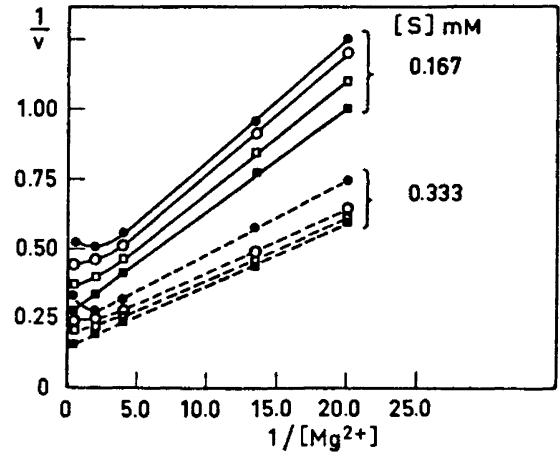

Fig. 8. The plot of the inverse value of the initial velocity $\left(1 / v\right.$; in $\left.\mathbf{M}^{-1} \times \min \times 10^{8}\right)$ versus the inverse value of $\mathrm{MgCl}_{2}$ concentration $\left(1 /\left[\mathrm{Mg}^{2+}\right]\right.$ : in $\left.\mathrm{mM}^{-1}\right)$ of the enzymatic hydrolysis of $p$-nitrophenyl phosphate, inhibited by the following $\mathrm{NaF}$ concentrations: $0 \mathrm{mM}(\square), \quad 1.0 \mathrm{mM}(\square), 1.33 \mathrm{mM}$ (O) and $1.67 \mathrm{mM}(0)$. Tested at the following $p$-nitrophenyl phosphate concentrations: $0.167 \mathrm{mM}(\stackrel{-}{-})$ and 0.333 $\mathrm{mM}(---)$.

Acta Chem. Scand. 27 (1973) No. 2 
obtained with potassium and lithium fluorides. The corresponding chlorides had no effect on the reaction velocity. The Dixon plots (Fig. 5 A) revealed noticeable curvature at $2.50 \mathrm{mM} \mathrm{MgCl}$ concentration, which leads to the highest rate of the hydrolysis of $p$-nitrophenyl phosphate at $0.167 \mathrm{mM}$ concentration. ${ }^{14}$

The curvature in the plot of Fig. $5 \mathrm{~A}$ indicates that the inhibition may take place in one or both of the following ways: (a) the inhibitor reacts with the substrate, or (b) two or more inhibitor molecules participate in the reaction with the enzyme site. To differentiate between these possibilities, the following plots were constructed:

(1) $1 / v$ versus the second power of the inhibitor concentration (Fig. 5 B). This showed that straight lines are obtained for all $p$-nitrophenyl phosphate concentrations used. However, this does not differentiate between the two possibilities.

(2) A plot of $[\mathrm{S}] / v$ versus $[\mathrm{S}]$ is presented in Fig. 6. From the same data also a plot of $1 / v$ versus $1 /[\mathrm{S}]$ was made (Fig. 7 ). The results in Figs. 5 B, 6, and 7 were obtained in the presence of $2.50 \mathrm{mM} \mathrm{MgCl}_{2}$ in the reaction mixture. The curvature of the plots of Figs. 6 and 7 suggests that most likely no binding of free fluoride ions to the active site of the enzyme has taken place, but rather a reaction between the substrate and the inhibitor. Consequently, the curvature of plot $1 / v$ versus [I] (Fig. $5 \mathrm{~A}$ ) is most likely due to reason (a) mentioned above.

Fig. 8 presents a plot of $1 / v$ versus $1 /\left[\mathrm{Mg}^{2+}\right]$ at two $p$-nitrophenyl phosphate concentrations. When the concentration of fluoride ions was increased, there was an increasing curvature at the highest $\mathrm{Mg}^{2}{ }^{+}$ion concentrations. The results of Fig. 8 support the earlier finding (Fig. 3) that the affinity of $\mathrm{Mg}^{2+}$ ions for the enzyme even in the presence of fluoride ions is not dependent on the con-

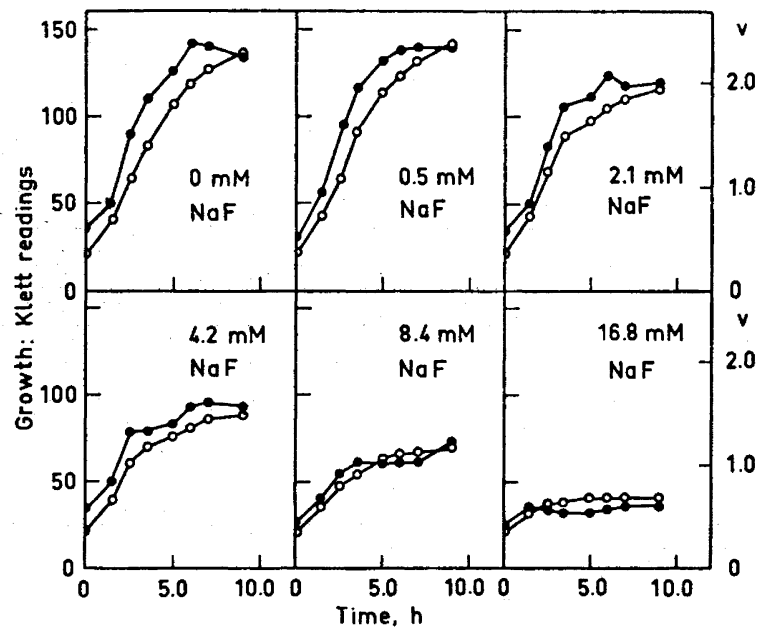

Fig. 9. The effect of NaF on the growth of Streptococcus mutans and on the synthesis of $p$-nitrophenylphosphatase. The enzyme preparations were obtained from sonicated cells of Streptococcus mutans, harvested from $5 \mathrm{ml}$ cell suspensions as described in Materials and Methods, and in earlier studies. ${ }^{14} \bigcirc$, growth of Str. mutans $\bigcirc$, hydrolysis of $p$ nitrophenyl phosphate $\left(v\right.$, in $\left.\mathbf{M} \times \min ^{-1} \times 10^{6}\right)$.

Acta Chem. Scand. 27 (1973) No. 2 
centration of $p$-nitrophenyl phosphate. Fluoride ions very slightly increased the affinity of $\mathrm{Mg}^{2+}$ ions for the enzyme, if the highest $\mathrm{MgCl}_{2}$ concentrations are not taken into consideration. The curvature at low values of $1 /\left[\mathrm{Mg}^{2+}\right]$ indicate that there is a type of substrate inhibition, if mere $\mathrm{Mg}^{2+}$ ions were also considered to represent the substrate (as a part of a complex between $p$-nitrophenyl phosphate and $\mathrm{Mg}^{2}{ }^{+}$ions). This inhibition appeared as a result of the highest fluoride concentration $(1.67 \mathrm{mM})$ used.

II. Effect of fluoride ions on the growth of the cells and the synthesis of the p-nitrophenylphosphatase

The fluoride ion concentration needed for effective inhibition of the growth of the cells is rather high (Fig. 9). The synthesis of $p$-nitrophenylphosphatase followed the growth pattern. The likely constitutive nature of the present enzyme was thus proved. The decrease of the synthesis of $p$-nitrophenylphosphatase is most likely a consequence of the general inhibition of cell growth, the fluoride ions affecting some vital reactions of the cells. ${ }^{16}$

\section{DISCUSSION}

The results show that (1) the apparent affinity of $\mathrm{Mg}^{2+}$ ions for the enzyme is not dependent on the concentration of $p$-nitrophenyl phosphate, and that (2) the apparent affinity of $p$-nitrophenyl phosphate is dependent on the concentration of $\mathrm{Mg}^{2+}$ ions.

These findings indicate that there are at least two different ways in which the substrate may be bound to the enzyme. (I) In the first alternative $\mathrm{Mg}^{2+}$ ions were separately bound close to the enzyme active site at a location where they do not compete with free $p$-nitrophenyl phosphate for the same enzyme site. $\mathrm{Mg}^{2+}$ ions would modify enzyme groups involved in the accomodation of the substrate, without reacting with the latter. (II) In the second alternative $\mathrm{Mg}^{2+}$ ions are combined with the enzyme, but the reacting substrate species is now represented by a $p$-nitrophenyl phosphate-Mg complex. In effect, there is a third possibility (III) which involves that $\mathrm{Mg}^{2}$ ions do not combine with the enzyme at all but only with $p$-nitrophenyl phosphate. Alternatives (I) and (III) are perhaps more unlikely than (II), but the present kinetic methods are insufficient to completely rule out these possibilities.

In general, the electrophilic function of metal ions in enzyme catalysis is due to the formation of a complex between the enzyme and metal cation, in which case alternative (III) can only be considered as being theoretical. No references supporting alternative I are available; however, the following findings, e.g. also support the idea of a $p$-nitrophenyl phosphate- $\mathrm{Mg}^{2+} \mathrm{com}$ plex in the present case: (a) In nonenzymatic hydrolysis of acetyl phosphate in the presence of $0.05 \mathrm{M} \mathrm{Mg}^{2+}$ ions the cleavage is predominantly at the $\mathrm{P}-\mathrm{O}$ bond. This is attributed to the formation of a chelate complex of dianionic species and $\mathrm{Mg}^{2+} .17$ (b) ATP forms complexes with $\mathrm{Mg}^{2+}$ and $\mathrm{Ca}^{2+}$ ions, which are necessary for the enzymatic action of adenosinetriphosphatase. ${ }^{18,19}$ (c) The substrate for the inorganic pyrophosphatase from bakers' yeast is a pyrophosphate-Mg complex. ${ }^{20}$ (d) Fig. 4 shows that the apparent affinity of both 
the substrate and the activator for the enzyme is the same, when tested at certain concentrations of the substrate $(0.167 \mathrm{mM}$ and $0.333 \mathrm{mM})$ and the activator $(0.25 \mathrm{mM}$ and $2.50 \mathrm{mM}$, respectively)). The double reciprocal plots indicate that in the conditions used the following reactions can be considered: (1) $\mathrm{Mg}^{2+}+p$-nitrophenyl phosphate $\rightleftharpoons \mathrm{Mg}-p$-nitrophenyl phosphate complex, $(2)$ $\mathrm{E}+\mathrm{Mg}-p$-nitrophenyl phosphate complex $\rightleftharpoons \mathrm{E}-\mathrm{Mg}-p$-nitrophenyl phosphate complex. Consequently, there are at least certain conditions where the above two reactions were likely. If there is a $p$-nitrophenyl phosphate- $\mathbf{M g}$ complex, its formation could take place before its binding to the enzyme or at the enzyme surface between separately bonded $p$-nitrophenyl phosphate and $\mathrm{Mg}^{2+}$ ions.

The results also show that: (1) Fluoride has most likely reacted with the substrate (Figs. $5 \mathrm{~A}, 6$, and 7). However, the possibility that two or more fluoride ions have reacted per each substrate molecule cannot be ruled out. (2) The apparent affinity of the substrate for the enzyme is decreased at increasing fluoride concentrations (Fig. 7). (3) Increasing fluoride concentrations slightly increase the apparent affinity of $\mathrm{Mg}^{2+}$ ions for the enzyme. Also the effect of fluoride most likely supports the earlier finding (Fig. 3) that the affinity of $\mathrm{Mg}^{2+}$ ions for the enzyme is not dependent on the concentrations of $p$ nitrophenyl phosphate (Fig. 8). (4) At high $\mathrm{MgCl}_{2}$ concentrations fluoride yielded slight curvature in the plots constructed (Fig. 8).

The different effects of fluoride on the affinity of both $p$-nitrophenyl phosphate (Fig. 7) and $\mathrm{Mg}^{2+}$ ions (Fig. 8) evidently support the assumption of independent binding sites for them. Elliot ${ }^{10}$ has shown that the inhibitory effect of fluoride ions on an alkaline pyrophosphatase can be explained in terms of a competition between a fluoromagnesium complex and $\mathrm{Mg}^{2+}$ ions for the enzyme. This would also be possible in the present case. However, it is known that the inhibitor most likely reacts with the substrate and affects its affinity for the enzyme. This may indicate that fluoride or a fluoromagnesium complex prevents the complex formation between $\mathrm{Mg}^{2+}$ ions and $p$ nitrophenyl phosphate. Such a complex would be necessary in the hydrolysis of $p$-nitrophenyl phosphate by the enzyme as previous suggested.

Another possibility would be based on the formation of a fluorophosphate complex, capable of forming a further complex with magnesium, as described in the case of enolase. ${ }^{1}$ Peters et al. ${ }^{4}$ have demonstrated, however, that fluorophosphate does not inhibit enolase, but is capable of forming a complex with magnesium, and also that the formation of $\mathrm{a} \mathrm{Mg}$ - fluorophosphate complex can not be the real mechanism of enolase inhibition by fluoride ions. The present results are insufficient to rule out the possibility of the complex between all three reactants: Fluorine, phosphate and $\mathrm{Mg}^{2+}$ ions. This has been shown to be true in the case of fluoride inhibition of DNA polymerase reaction. ${ }^{21}$

As to the possibility that two fluorine atoms could be bound per substrate molecule it should be noticed that inorganic fluoride exists in ionized form in the $\mathrm{pH}$ range $6-9 .^{22}$ At progressively lower $\mathrm{pH}$ values both $\mathrm{HF}$ (the free acid) and $\left(\mathrm{HF}_{2}\right)^{-}$(the associated form) are present in increasing quantities. The pre-

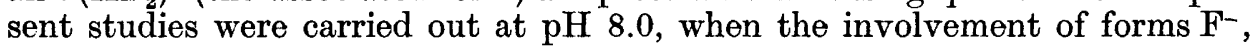
$2 \mathrm{~F}^{-}$, and $\mathrm{F}_{2}{ }^{2-}$ could be evident. 
Acknowledgements. Thanks are due to the National Research Council for Medical Sciences, Finland, for financial support (to M.L.E.K.). The technical assistance of Miss Rauni Suominen is gratefully acknowledged.

\section{REFERENCES}

1. Warburg, O. and Christian, W. Naturwiss. 29 (1941) 590.

2. Warburg, O. and Christian, W. Biochem. Z. 310 (1942) 384.

3. Boser, H. Naturwiss. 44 (1957) 586.

4. Peters, E. A., Shorthouse, M. and Murray, L. R. Nature 202 (1964) 1331.

5. Cimasoni, G. Abstr. XVII Orca Congr. Debrecen, Hungary 1970.

6. Roche, J. and Thoai, N. V. Advan. Enzymol. 10 (1950) 83.

7. Belfanti, S., Contardia, A. and Ercoli, A. Biochem. J. 29 (1935) 842.

8. Reiner, J. M., Tsubol, K. K. and Hudson, P. B. Arch. Biochem. Biophys. 56 (1955) 165.

9. Meyers, D. K. and Slater, E. C. Biochem. J. 65 (1967) 572.

10. Elliot, W. H. Biochem. J. 65 (1957) 315.

11. Smith, Q. T., Armstrong, W. D. and Singer, L. Proc. Soc. Exp. Biol. Med. 102 (1959) 170.

12. Mircevova, L. and Simonova, A. Collection Czech. Chem. Commun. 35 (1970) 2996.

13. Hewitt, E. J. and Nicholas, J. D. In Hochester R. M. and Quastel, J. H., Eds., Metabolic Inhibitors, Academic, New York 1963, Vol. 2, p. 311.

14. Knuuttila, M. L. E. and Mäkinen, K. K. Arch. Biochem. Biophys. 152 (1972) 685. publication.

15. Bessey, O. A., Lowry, O. H. and Brock, M. J. J. Biol. Chem. 164 (1946) 321.

16. Kanapka, J. A., Khandelwal, R. L., and Hamilton, I. R. Arch. Biochem. Biophys. 144 (1971) 596.

17. Morton, R. K. In Florkin, M. and Stotz, E. H., Eds., Comprehensive Biochemistry, Elsevier, Amsterdam 1965, Vol. 16, p. 55.

18. Williams, R. J. P. In Boyer, P. D., Lardy, H. and Myrbäck, K., Eds., The Enzymes, Academic, New York 1959, Vol. 1, p. 391.

19. Kosower, E. M. Molecular Biochemistry, McGraw, New York 1962, p. 227.

20. Rapoport, T. A., Höhne, W. E., Reich, J. G., Heitman, P. and Rapoport, S. M. Europ. J. Biochem. 26 (1972) 237.

21. Hellung-Larsen, R. P. and Klenow, H. Biochim. Biophys. Acta 190 (1969) 434.

22. Wieseman, A. In Smith, F. A., Ed., Handbook of Experimental Pharmacology, Springer, Berlin 1970, Vol. XX/2, p. 48.

Received June 27, 1972. 